\title{
Growth and Development of Bananas (Musa sp.) Cultivated in Agroecological Systems in Northeastern Brazil
}

\author{
José Aluisio de Araújo Paula ${ }^{1}$, Eudes de Almeida Cardoso $^{2}$, Janilson Pinheiro de Assis ${ }^{2}$, \\ Elizângela Cabral Santos ${ }^{2}$, Roberto Pequeno de Sousa ${ }^{2}$, Paulo César Ferreira Linhares ${ }^{2}$ \\ $\&$ Stefeson Bezerra De Melo ${ }^{2}$ \\ ${ }^{1}$ Brazilian Service to Support Micro and Small Enterprises, Mossoró, RN, Brazil \\ 2 Jitirana Research Group, Department of Agronomic and Forestry Sciences, Federal Rural Semi-Arid University, \\ Mossoró, RN, Brazil \\ Correspondence: José Aluisio de Araújo Paula, Brazilian Service to Support Micro and Small Enterprises, \\ Mossoró, RN, Brazil. E-mail: aluisiopaula@gmail.com
}

Received: August 23, 2018

doi:10.5539/jas.v10n12p366
Accepted: September 27, $2018 \quad$ Online Published: November 15, 2018

URL: https://doi.org/10.5539/jas.v10n12p366

\begin{abstract}
The banana is the most eaten tropical fruit and the second most harvested in the world, losing only to the orange. In this research, we aimed to evaluate the growth and development of different banana cultivars in response to the use of different types of seedlings and management methods used for plant propagation in agro-ecological systems. An experiment under randomized block design was applied in a factorial scheme of $2 \times 2 \times 2$, with four blocks and two replicates in each block. The treatments comprised all combinations of the following sources of variation: cultivar-'Pacovan' and 'Prata-anã'; seedlings weight—-between 0.5 to $1.0 \mathrm{~kg}$ and above $1.0 \mathrm{~kg}$; and method of propagation by rhizomes - with and without the acclimatization technique called "ceva". The efficiency of each treatment was measured as the number of days to occur the following events: first sprouting, flowering, final harvest and the interval between flowering and harvest. No source of variation affected the day of flowering. Therefore, we fixed the value of flowering days as 260 , independently of the cultivar or method of propagation. The analysis of the coordinate factors revealed that the variables that best explained the studied events were period of final harvest (92\%), followed by interval between flowering and harvest $(75 \%)$ and period of initial sprouting (71\%). The propagation of 'Prata-anã' without "ceva" had the greatest efficiency, where as the propagation of 'Pacovan' without "ceva" had the worse efficiency. The propagations with "ceva" obtained intermediate values.
\end{abstract}

Keywords: number of sprouts, flowering interval, agroecology

\section{Introduction}

The banana is the most eaten tropical fruit and the second most harvested in the world, losing only to the orange. Due to its nutritive features, accessibility, and year-round availability, banana is the fourth most consumed food product in the world in 2010 (FAO, 2012). In Brazil, the banana stands out with the second highest volume of production (Anuário Brasileiro da Fruticultura, 2014). Around 97076479 tons were produced in 2013, grown in an area of 483915 ha. The leading national producers are the states of Bahia, São Paulo, Minas Gerais, Santa Catarina, Pará, Ceará, and Pernambuco. Farmed mostly by small farms, banana cultivation plays an important socio-economic role in many emerging countries, contributing not only to income-generation but also to keep the populations in rural areas. Estimates indicate that the culture is responsible for more than 500 thousand direct jobs (Anuário Brasileiro da Fruticultura, 2014).

The state of Rio Grande do Norte ranks as the eleventh largest National producer, but if we add the indices obtained in the States of Ceará and the Rio Grande do Norte, these together are similar to those of São Paulo, rising to the second place in crop area ranking ( $52470.00 \mathrm{ha}, 10.98 \%$ of the total harvested area), the fifth place in quantity of production (623602 tons, $9.00 \%$ of total), the sixth in average yield $(11884.96 \mathrm{~kg} / \mathrm{ha}$ ), the second in the increase of production in relation to the previous crop $(19.92 \%)$, the fourth place in gross income (R\$ 470670000.00), and the sixth place of profit per unit area (R\$ 8970.27/ha) (IBGE, 2014; Paula, 2017). 
The banana tree (Musa spp.) propagates both by seed and by seedlings, this last one being the most usual and efficient. In the conventional propagation system, 40 or more seedlings can be produced from the separation of sprouts from the parent rhizome, but not all of them develop satisfactorily (Alves et al., 1999; Borges et al., 2004).

According to Rangel et al. (2017), seedlings of not sprouted rhizome should be used whole or subdivided in half or four parts (weighing more than $500 \mathrm{~g}$ each). Such seedlings show slower development and a longer first cycle of production. In practice, the heavier the seedlings, the faster their development.

Melo et al. (2017) evaluated the preparation of banana tree seedlings in the agroecological system of the region of the Açu Valley, semi-arid Region of Northeastern Brazil. The authors used in the pre-planting phase, cleaning the rhizomes with knives and machetes to remove all adhered soil, pseudocaule remains, roots and wounds or galleries of banana weevil. After that, the rhizomes, depending on the size, were divided into two, three or four pieces of approximately $1 \mathrm{~kg}$, which were then used as matrices in the production of seedlings.

Guerra et al. (2009) state that in the banana agribusiness of Açu Valley, seedling production influences phytosanitary quality due to problems with nematodes, rhizome weevil, Panama disease, soft rot, yellow Sigatoka and viruses that can be carried by the seedlings obtained by the conventional method. They suggest that the use of rhizome seedlings must undergo a technique of acclimatization called "ceva" for a period of 45 to 60 days, before the final planting.

The "ceva" is a process where favorable conditions are given to the banana seedlings to help the beginning of development of its root system and accelerate the swelling of the lateral sprouts (Mendonça et al., 2003). For this, preselected rhizomes undergo a fallow (rest) on the soil surface, in shaded places, for 21 days before planting.

Unlike the agroecological management, industrial agriculture and monocultures in conventional management systems cause many economic, environmental, and social problems. Conventional farming techniques lead to negative impacts on public health, ecosystem integrity, food quality, and disruption the traditional rural livelihoods, accelerating the indebtedness of thousands of farmers (Altieri, 2010).

Based on agro-ecological principles, Maia et al. (2011) studying genotypes of banana propagated in an agro-ecological system, verified that the biofertilizer dosage of $1.5 \mathrm{~L} /$ plant/month increased the plant height and leaf area at the first cycle.

In this research, we aimed to evaluate the growth and development of different banana cultivars in response to the use of different types of seedlings and management techniques used for the propagation of plants in agro-ecological management.

\section{Material and Methods}

Our experiment tested the response of banana cultivars to propagation techniques applied in the agro-ecological systems. The study was carried out in the Rafael Fernandes Experimental Farm (50 $0^{\prime} 36.7^{\prime \prime} \mathrm{S}$ and $\left.37^{\circ} 24^{\prime} 6.6^{\prime \prime} \mathrm{W}\right)$, Mossoró, Rio Grande do Norte, Brazil. The region is known as "agropolo Assú/Mossoró", and according to the classification of Köppen, the climate is BSwh' (hot and dry).

We applied a randomized block design in a $2 \times 2 \times 2$ factorial scheme, with four blocks and two replicates in each block. The treatments comprised all combinations of the following sources of variation: cultivar-'Pacovan' and 'Prata-anã'; seedlings weight — between 0.5 to $1.0 \mathrm{~kg}$ and above $1.0 \mathrm{~kg}$; and method of propagation by rhizomes - with and without the "ceva" acclimatization.

The experimental area consisted of 64 plants distributed in eight plots, with two replicates per treatment in each block, and four blocks. Each block was intercalated by two border plants, planted in a single row with the rectangular form, in pits of $0.40 \mathrm{~m}$ depth and spacing $2.7 \times 4.0 \mathrm{~m}$, respectively between plants and between rows. The border area of the experiment comprised 64 plants, with two plants distributed for each set of 2 replicates per plot in each block. The total area was $1,382.40 \mathrm{~m}^{2}$, distributed in 128 plants, making an area of 10.80 $\mathrm{m}^{2} /$ plant.

Before the treatments of propagation with and without "ceva", the rhizome tillers of the selected cultivar were ripped from the soil and transported to the study area. The leaves were removed, and the rhizomes were put in greenhouses with shade cloth and compacted soil. The rhizomes remained in the greenhouse for up to one day before its final transplanting, when the seedling was prepared by scraping with a knife for the elimination of excess roots and removal of necrotic tissues. The rhizomes were weighed to separate the ones with 0.5 to $1.0 \mathrm{~kg}$ and the ones with more than $1.0 \mathrm{~kg}$. 
After the plowing and harrowing of the experimental area and before the planting, we carried out the physical-chemical analyzes of soil (0-30 and 30-60 cm depth) and chemical analyses of the farm water. The results of the soil and water analysis were used to determine the local conditions for the conduction of the experimental plants and to evaluate the application of macro-micronutrients. The mineral fertilization occurred by the application of N-P-K, formulation 4-14-8, in the soil, or the supply of these and other nutrients involuntarily via soil and water. We also estimated the irrigation deep, the irrigation period, and the speed of infiltration to supply the experiment in different stages of development and avoid a runoff. The soil texture in both depths was sandy.

The phytosanitary and weed control was carried out in a preventive way, applying biological control, burning the native plants contaminated with diseases common to the culture under study. We also removed the weeds and deposited the dry matter on the soil surface to serve as mulch and place to shelter natural enemies of pests.

The supply of inputs in the experimental area was carried out following the guidelines of Alves (1999), subtracted from the values found in soil analyzes (Table A1) and water (Table A2), and divided into three stages. In the initial fertilization, we used $57 \mathrm{~kg}$ of cattle manure and $40 \mathrm{~g}$ of N-P-K mineral fertilizer per plant in the formulation 4-14-8 (167.4 and $37.04 \mathrm{~kg} / \mathrm{ha}$, respectively). The other fertilization steps occurred two months after the first one and five months after the second. We applied, in each one, the mineral fertilizers $\mathrm{KCl}$, Urea, and Magnesium sulfate, in the amounts of 51, 38 and $43 \mathrm{~g} / \mathrm{plant}$, or $47.23,35.46$ and $39.82 \mathrm{~kg} / \mathrm{ha}$ in the soil, making a total of two applications with fertilizers of $94.46,70.93$, and $79.64 \mathrm{~kg} / \mathrm{ha}$, respectively.

The water supply was done following the weekly/daily reference evapotranspiration estimated for the crop obtained as recommended by the FAO, Food and Agriculture Organization of the United Nations, (Allen et al., 2018). The water replacement was performed through a drip irrigation system.

To propagate the rhizome with "ceva", we got seedlings with 15 to 22 days of acclimatization (average of 18 days). To propagate rhizomes without "ceva", the seedlings were collected in a transplant period of one day.

The efficiency of each treatment was measured as the number of days to occur the following events: interval from planting to initial budding of plants (Sprouting), interval from planting to tea at flowering (Flowering), interval between flowering and harvesting (Flowering $\rightarrow$ Harvest or $\mathrm{F} \rightarrow \mathrm{H}$ ) and the total harvest interval (Harvest).

The differences among treatments were tested using Analysis of Variances (F Test) and subsequent unfolding tests. The analyses were carried out in the software Sisvar ${ }^{\circledR}$ (Gomes, 2009; Ferreira, 2017).

We also applied a multivariate statistic using the software Statistica $13^{\circledR}$ (Alvarez, 2017), only the variables that obtained significant results in the ANOVA. We performed an analysis of hierarchical clustering as proposed by the single bond method of Euclidean distances. Then, the principal components were applied with the matrix of correlations and coordinate factors (Moita Neto, 2017; Manly, 2008).

\section{Results and Discussion}

There was no significant effect for any source of variation on the number of flowering days. Therefore, we fixed the flowering day at 260 , independently of the cultivar or propagation method (Table 1).

Donato et al. (2006), studying banana of 'Prata-anã' and 'Pacovan' cultivars in the first cycle, also found statistically similar results for the cultivars, with the flowering occurring at 225 days after planting. Lédo et al. (2008), also studying the first cycle of these cultivars, found that the 'Prata-anã' cultivar flowered at 208 days, and the 'Pacovan' cultivar at 240 days. 
Table 1. Analysis of variance (F-test), coefficient of variation, and average values of growth and development characteristics of banana trees (Musa sp.) cultivated under agroecological techniques. Mossoró/RN, 2018

\begin{tabular}{|c|c|c|c|c|c|}
\hline \multirow{2}{*}{ Source of variation } & \multirow{2}{*}{$\mathrm{df}$} & \multicolumn{4}{|c|}{ Days required for the occurrence of an event } \\
\hline & & Sprouting & Flowering $(\mathrm{F})$ & Harvest $(\mathrm{H})$ & $\mathrm{F} \rightarrow \mathrm{H}$ \\
\hline Cultivar (C) & 1 & $0.0063 * *$ & $0.1035^{\mathrm{ns}}$ & $0.0091 * *$ & $0.2016^{\mathrm{ns}}$ \\
\hline Propagation by seedlings between 0.5 and $1.0 \mathrm{~kg}$ (M1) & 1 & $0.9549^{\mathrm{ns}}$ & $0.2729^{\mathrm{ns}}$ & $0.3776^{\mathrm{ns}}$ & $0.0451 *$ \\
\hline Propagation by seedlings with and without "ceva" (M2) & 1 & $0.7491^{\mathrm{ns}}$ & $0.6484^{\mathrm{ns}}$ & $0.4718^{\mathrm{ns}}$ & $0.7619^{\mathrm{ns}}$ \\
\hline $\mathrm{C} \times \mathrm{M} 1$ & 1 & $0.0629^{\mathrm{ns}}$ & $0.0511^{\mathrm{ns}}$ & $0.4045^{\mathrm{ns}}$ & $0.2330^{\mathrm{ns}}$ \\
\hline $\mathrm{C} \times \mathrm{M} 2$ & 1 & $0.0029 * *$ & $0.4664^{\mathrm{ns}}$ & $0.0119 *$ & $0.0404 *$ \\
\hline $\mathrm{M} 1 \times \mathrm{M} 2$ & 1 & $0.0430 *$ & $0.7762^{\mathrm{ns}}$ & $0.1894^{\mathrm{ns}}$ & $0.2608^{\mathrm{ns}}$ \\
\hline $\mathrm{C} \times(\mathrm{M} 1 \times \mathrm{M} 2)$ & 1 & $0.1120^{\mathrm{ns}}$ & $0.2321^{\mathrm{ns}}$ & $0.0719^{\mathrm{ns}}$ & $0.4566^{\mathrm{ns}}$ \\
\hline Blocks & 3 & & & & \\
\hline Residuals & 21 & & & & \\
\hline Total & 31 & & & & \\
\hline CV $(\%)$ & & 19.69 & 7.78 & 5.94 & 21.04 \\
\hline Average & & 23.55 & 260.34 & 353.41 & 93.06 \\
\hline
\end{tabular}

Note. ${ }^{\mathrm{ns}}$ not significant; ${ }^{*} \mathrm{p}<0.05 ; * * \mathrm{p}<0.01$.

The values flowering day obtained in our trial exceeded all values found in studies developed under similar conditions. Our bananas flowered later even when compared to studies under different conditions, for example, the 'Pacovan-Ken' cultivar flowered at 254 days and the 'Pacovan' at 232 days (Azevedo et al., 2010).

The kind of cultivar affected the days for initial sprouting and the days for final harvest $(\mathrm{p}<0.01)$. Also, the interaction between cultivar and the use or not of "ceva" affected the day of first sprouting $(\mathrm{p}<0.01 ;$ Table 1$)$.

The Propagation by seedlings between 0.5 and $1.0 \mathrm{~kg}$ (M1) and the interaction between cultivar (C) and the Propagation by seedlings with and without "ceva" (M2) affected the interval between flowering and harvest ( $p<$ 0.05). The interaction between cultivar and the use or not of "ceva" also affected the day of final harvest ( $\mathrm{p}<$ 0.05), while the interaction between Propagation by seedlings between 0.5 and $1.0 \mathrm{~kg}$ and the use or not of "ceva" affected the day of initial sprouting $(\mathrm{p}<0.05)$ (Table 1$)$.

The multivariate analyses addressed only the variable days of initial sprouting, days of final harvest, and the interval between flowering and harvest, neglecting the days of flowering since this variable suffered no significant effect from the studied factors.

The hierarchical clustering analysis showed that the variables analyzed are divided into two groups, which show that days of final harvest (ITC) correlates with the interval from flowering to harvest (IFC), while the initial sprouting day (IBR) does not correlate with the others (Figure 1).

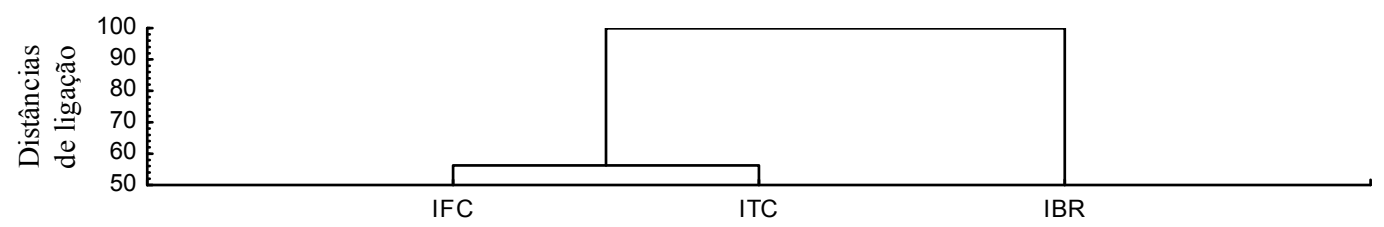

Figure 1. Dendrogram of the hierarchical clustering analysis developed for the study of banana (Musa sp.) cultivated in an agro-ecological system. Mossoró/RN. 2018

The principal Component Correlation Matrix (CCM) analysis confirmed the lack or low correlation between the initial sprouting day and the interval from flowering to harvest (18\%) (Table 2). The period of final harvest correlates both with the interval between flowering and harvest $(60 \%)$ and the initial sprouting $(56 \%)$. 
Table 2. Correlation matrix for the main components of the study of banana (Musa sp.) cultivated in an agro-ecological system. Mossoró/RN, $2018^{1}$

\begin{tabular}{llll}
\hline \multirow{2}{*}{ Variables } & \multicolumn{3}{c}{ Days required for the occurrence of an event } \\
\cline { 2 - 4 } & Initial Sprouting & Flowering to harvest & Final Harvest \\
\hline Final Harvest & 0.56 & 0.60 & 1.00 \\
Flowering to harvest & 0.18 & 1.00 & - \\
Initial Sprouting & 1.00 & - & - \\
\hline
\end{tabular}

Note. ${ }^{1}$ All values in each column are dimensionless.

Taking in account all analysis, we may conclude that anticipation or delay in initial sprouting period did not affect the number of days between flowering to harvesting (the phase of fruit growing), but affect significantly the days required for final harvest (Tables 1 and 2, and Figure 1). Also, the fruit growth interval (day between flowering and harvest) was influenced only by the day of final harvest (Tables 1 and 2, and Figure 1).

The cumulative effect of the correlations showed that three factors explained $100 \%$ of the events (Table 3 ), but only the factor 1 was necessary to explain all the possibilities of the trial (eigenvalue $>1.00$ ).

Table 3. Eigenvalues of correlation matrix factors for bananas cultivated in agro-ecological management. Mossoró/RN, 2018

\begin{tabular}{lllll}
\hline Variable & Eigenvalue & Percentage of total variance (\%) & Cumulative eigenvalue & Cumulative Percentage (\%) \\
\hline factor 1 & 1.913419 & 63.78064 & 1.913419 & 63.7806 \\
factor 2 & 0.821449 & 27.38163 & 2.734868 & 91.1623 \\
factor 3 & 0.265132 & 8.83772 & 3.000000 & 100.0000 \\
\hline
\end{tabular}

The analysis of the coordinate factors revealed that the variables that best explained the studied events were period of final harvest (92\%), followed by interval between flowering and harvest (75\%) and period of initial sprouting (71\%) (Table 4).

Table 4. Factor of coordinates for bananas (Musa sp.) cultivated in an agroecological system. Mossoró/RN, 20181

\begin{tabular}{ll}
\hline Variables & Factor 1 (\%) \\
\hline Day of initial sprouting & 0.71 \\
Days from flowering to harvest & 0.75 \\
Day of final harvest & 0.92 \\
\hline
\end{tabular}

Note. ${ }^{1}$ All values in each column are dimensionless.

When propagated without "ceva", the 'Prata-anã' cultivar began the sprouting earlier (19 days) than the 'Pacovan' cultivar (29 days). While, when propagated with "ceva", the beginning of sprouting was similar for the two cultivars (Table 5).

The use of "ceva" significantly anticipated initial sprouting in 'Pacovan' (23 days) when compared to the propagation without "ceva" (29 days). The 'Prata-anã' cultivar sprouted earlier when not submitted to "ceva" (19 days) than in acclimatized treatments (24 days) (Table 5).

The best treatment for initial sprouting was 'Prata-anã' cultivar without "ceva", followed by both cultivars with "ceva", and finally the propagation of 'Pacovan' without "ceva" (Table 5). 
Table 5. Mean values of the initial sprouting day of the banana plants, referring to the unfolding of the interaction between cultivar and the use or not of "ceva". Mossoró/RN, 2018 "

\begin{tabular}{lll}
\hline Cultivar & Without "ceva" & With "ceva" \\
\hline 'Pacovan' & $29^{\mathrm{Aa}}$ & $23^{\mathrm{Ab}}$ \\
'Prata-anã' & $19^{\mathrm{Bb}}$ & $24^{\mathrm{Aa}}$ \\
\hline
\end{tabular}

Note. ${ }^{1}$ In each row and in each column, averages followed by the same upper and lower case letters do not differ from each other by the F-test.

Still regarding the initial sprouting, when combining the Propagation by seedlings between 0.5 and $1.0 \mathrm{~kg}$ (M1) with Propagation by seedlings with and without "ceva" (M2), the best results were obtained when seedlings were propagated with rhizome weighing from 0.5 to $1 \mathrm{~kg}$ with "ceva" and with weights above $1 \mathrm{~kg}$ without "ceva" (21 and 22 days, respectively). The second best propagations were rhizome of 0.5 to $1 \mathrm{~kg}$ without "ceva" and weights above $1 \mathrm{~kg}$ with ceva (25 and 25 days respectively) (Table 6).

Analyzing all significant results, we suggest that for anticipate initial sprouting, the best option for banana propagation in agro-ecological model was the use of 'Prata-anã' cultivar with rhizome weighing more than $1 \mathrm{~kg}$ without "ceva", followed by the 'Pacovan' cultivar with rhizome weighing 0.5 to $1 \mathrm{~kg}$ with "ceva" (Tables 5 and 6).

Table 6. Mean values of the initial sprouting day of the banana plants, referring to the unfolding of the interaction between propagation M1 and M2. Mossoró/RN, $2018^{1}$

\begin{tabular}{lll}
\hline & Without "ceva" & With "ceva" \\
\hline Rhizome weight between 0.5 and $1 \mathrm{~kg}$ & $25 \mathrm{Aa}$ & $21 \mathrm{Bb}$ \\
Rhizome weight above than $1 \mathrm{~kg}$ & $22 \mathrm{Bb}$ & $25 \mathrm{Aa}$ \\
\hline
\end{tabular}

Note. ${ }^{1}$ In each row and in each column, averages followed by the same upper and lower case letters do not differ from each other by the F-test.

Melo et al. (2017), also studying 'Pacovan' propagation, obtained initial sprouting after 30 days of planting. In our essay, the most linger sample reached 29 days for initial sprouting. All other rhizomes sprouted early (Tables 5 and 6).

Melo et al. (2017) explained that the delay obtained in the initial sprouting in their study was due to the addition of a step during the sanitization process (a hydrothermal treatment with sodium hypochlorite), which prevents the attack of the banana weevil.

This justification, however, does not explain the delay in sprouting of our 'Pacovan' propagated without "ceva", because we did not apply the phytosanitary treatment proposed by Melo et al. (2017). Thus, our results occurred simply because of the inefficiency of the production of 'Pacovan' without "ceva".

The best result for the flowering-harvest interval was 85 days, reached with the propagation M1 and rhizomes weighing between 0.5 to $1 \mathrm{~kg}$. This period lasted 100 days when propagation was done with rhizomes weighing more than $1.0 \mathrm{~kg}$ (Table 7).

Table 7. Average values of the interval between flowering and harvest of the banana crops, referring to Propagation by seedlings between 0.5 and $1.0 \mathrm{~kg}$ (M1). Mossoró/RN, $2018^{1}$

\begin{tabular}{ll}
\hline Source of variation & Days from flowering to harvest \\
\hline Rhizome weight between 0.5 and $1 \mathrm{~kg}$ & $85^{\mathrm{B}}$ \\
Rhizome weight above than $1 \mathrm{~kg}$ & $100^{\mathrm{A}}$ \\
\hline
\end{tabular}

Note. ${ }^{1}$ In each row, averages followed by the same letters do not differ from each other by the F-test.

Still referring to the interval between flowering and harvesting, when propagated without "ceva", the cultivar 'Prata-anã' required fewer days than 'Pacovan' (89 and 106 days, respectively). The cultivars did not affect the fruit development period when cultivated with "ceva" (Table 8). 
The time required for fruit development was significantly lesser for 'Pacovan' cultivated with "ceva" (89 days) than without "ceva" (106 days). The 'Prata-anã' showed the opposite response, fewer days without "ceva" (82 days) than with "ceva" (95 days) (Table 8).

Table 8. Average values of the interval between banana flowering and harvest, referring to the unfolding of the interaction between cultivar and Propagation by seedlings with and without "ceva" of propagation. Mossoró/RN, $2018^{1}$

\begin{tabular}{lll}
\hline Cultivar & Without "ceva" & With "ceva" \\
\hline 'Pacovan' & $106^{\mathrm{Aa}}$ & $89^{\mathrm{Ab}}$ \\
'Prata-anã' & $82^{\mathrm{Bb}}$ & $95^{\mathrm{Aa}}$
\end{tabular}

Note. ${ }^{1}$ In each row and in each column, averages followed by the same upper and lower case letters do not differ from each other by the F-test.

The best flowering-harvest interval was obtained by the propagation of 'Prata-anã' without "ceva", followed by both cultivars with "ceva", and finally the propagation of 'Pacovan' without "ceva" as the worst option (Table 8).

Our results for the 'Pacovan' (106 days) flowering-harvest interval were better than the results of several studies developed in Brazil for the same environmental conditions, for example 'Pacovan' (135 days) and 'Dwarf Silver '(137 days) obtained by Donato et al. (2006); 'Pacovan' (119 days) and 'Prata-anã' (153 days) studied by Lédo et al. (2008); 'Pacovan' (154 days) obtained by Azevedo et al. (2010). These numbers demonstrate the efficiency and superiority of the treatments and management that we apply..

For the final harvest day, when cultivated without "ceva", the 'Prata-anã' cultivar required less time (351 days) then 'Pacovan' (377 days). When grown with “ceva”, the cultivars did not differ between themselves (Table 9).

Still regarding final harvest day, 'Pacovan' required fewer days when cultivated with "ceva" (351 days) than when acclimatization was not used (377 days). Whereas, the 'Prata-anã' showed the opposite behavior, needing less time when not submitted to "ceva" (335 days) than when we applied the "ceva" (350 days) (Table 9).

Unfolding the interaction between cultivars and Propagation by seedlings with and without "ceva" (M2), the earliest final harvest occurred with the propagation of 'Prata-anã' without "ceva", followed by both cultivars grown with "ceva", and the propagation of 'Pacovan' without "ceva", as the worst option (Table 9).

Table 9. Mean values of the final banana harvest day, related to the unfolding of the interaction between cultivars and method of propagation M2. Mossoró/RN, $2018^{1}$

\begin{tabular}{lll}
\hline Cultivar & Without "ceva" & With "ceva" \\
\hline 'Pacovan' & $377^{\mathrm{Aa}}$ & $351^{\mathrm{Ab}}$ \\
'Prata-anã' & $335^{\mathrm{Bb}}$ & $350^{\mathrm{Aa}}$
\end{tabular}

Note. ${ }^{1}$ In each row and in each column, averages followed by the same upper and lower case letters do not differ from each other by the F-test.

Our best results for final harvest day overcame the results obtained by Donato et al. (2006) testing 'Pacovan' (360 days) and 'Prata-anã' (362 days), Lédo et al. (2008) testing 'Pacovan' (360 days) and 'Prata-anã' (360 days), and Azevedo et al. (2010) studying 'Pacovan' (386 days). However, our worst result was better only than the 'Pacovan' (386 days) studied by Azevedo et al. (2010). Demonstrating that most of our treatments were efficient and superior to many treatments suggested in the literature.

Analyzing the results obtained in the Hierarchical Clustering and the Principal Component Correlation (Figure 1 and Table 2) and the results of ANOVA for initial sprouting day, interval between flowering and harvest, and final harvest (Tables 5, 6, 8, and 9), we observe that the faster the sprouting or the flowering-harvest interval, the earlier the final harvest day. The first two variables were correlated with each other and with the final harvest date for the interaction between cultivars and Propagation by seedlings with and without "ceva", where best results were obtained in the propagation of 'Prata-anã' without "ceva", and the worst 'Pacovan' also without "ceva". The propagations of both cultivars without "ceva" were statistically similar and showed intermediate results when compared to treatments without "ceva". 
Because the final harvest day explained $92 \%$ of the events, it can be used as a good indicator to surrogate the other variables. It also points out that the propagation of 'Pacovan' without "ceva" was inefficient in the management of plants for agro-ecological systems in the studied conditions. This source of variation, however, also revealed inefficiency to explain the initial sprouting date of the plants and the flowering-harvest interval (Tables 4, 5 and 7), which explained, respectively, 71 and $75 \%$ of the events occurred in the present study.

For the interval between flowering and harvest (75\%) and for the initial sprouting day $(71 \%)$, the variables that had the most significant influence to indicate that the propagation of plants by rhizome weighing higher than 1.0 $\mathrm{kg}$ and by seedlings with rhizome weighing between 0.5 to $1 \mathrm{~kg}$ propagated without "ceva", respectively, For the variables interval between flowering and harvest (75\%) and initial sprouting interval of the plants $(71 \%)$, which also had significant influence to indicate that the propagation of plants per rhizome weighs more than $1.0 \mathrm{~kg}$ and per rhizome with rhizome weight between 0.5 and $1 \mathrm{~kg}$ propagated without "ceva", respectively, had values equally unfavorable to those obtained both for each individual variable and for their unfolding in the propagation of 'Pacovan' without "ceva" (Tables 4, 5, 6, 8 and 9).

These two sources of variation affected only individual variables, not the three variables collectively or the final harvest day, which represented $92 \%$ of the events. Therefore, they cannot be considered as inefficient globally and conclusively, because in our study proved it only with the source of variation 'Pacovan' without "ceva". Therefore, this source of variation was the least efficient, and the propagation of the cultivar 'Prata-anã' without "ceva" as the most efficient and the propagation of both cultivars with "ceva" as intermediates to the propagations without "ceva" (Tables 4, 5, 6, 8 and 9).

\section{Conclusions}

The best initial sprouting interval obtained in the study was the propagation of the cultivar 'Prata-anã' with rhizome weight of more than $1 \mathrm{~kg}$ and without 'ceva', and it is possible to adopt as an alternative option the propagation of 'Pacovan' cultivar with rhizome, weighing between 0.5 and $1 \mathrm{~kg}$ with "ceva";

The shortest interval between flowering and harvest of the study was obtained in propagules of cultivars with rhizomes weighing between 0.5 and $1.0 \mathrm{~kg}$; and

The propagation of the cultivars Prata-anã and Pacovan without "ceva" were, respectively, the one of greater and smaller efficiency in the conduction of plants for the agroecological model studied, whereas the propagation of the cultivars Prata-anã and Pacovan with "ceva" obtained values equally intermediate to the first two.

\section{References}

Allen, R. G., Pereira, L. S., Raes, D., \& Smith, M. (2018). Crop evapotranspiration: Guidelines for computing crop water requirements (p. 297). Rome: FAO. https://doi.org/10.1016/j.cj.2017.10.005

Altieri, M. (2010). Agroecologia, agricultura camponesa e soberania alimentar. Revista Nera, 13(16), 22-32.

Alvarez, M. (2017). Manejo Básico de Statistica. Retrieved from: http://ftp.ufv.br/dti/statistica/

Alves, J. E. (1999). A cultura da banana: aspectos técnicos, socioeconômicos e agroindustriais (2nd ed., p. 585). Brasília: Embrapa-SPI.

Anuário Brasileiro da Fruticultura. (2014). Brasilian Fruit: Yearbook 2014 (p. 140). Brasilia: Editora Gazeta.

Azevedo, V. F., Donato, S. L. R., Arantes, A. M., Maia, V. M., \& Silva, S. O. (2010). Avaliação de bananeiras tipo prata, de porte alto, no semiárido. Ciência e Agrotecnologia, 34(6), 1372-1380. https://doi.org/10.1590/ S1413-70542010000600003

Borges, A. L., \& Souza, L. S. (2004). O cultivo da bananeira (p. 279). Cruz das Almas: Embrapa Mandioca e Fruticultura.

Donato, S. L. R., Silva, S. O., Lucca Filho, O. A., Lima, M. B., Domingues, H., \& Alves J. S. (2006). Comportamento de variedades e híbridos de bananeira (Musa spp.), em dois ciclos de produção no sudoeste da Bahia. Revista Brasileira de Fruticultura, 28(1), 139-144. https://doi.org/10.1590/S0100-2945200600 0100039

FAO (Food and Agriculture Organization of the United Nations). (2012). Faostat Database Results. Maintained by FAO, Roma. Retrieved from http://apps.fao.org

Ferreira, D. F. (2017). Sisvar: A computer statistical analysis system for windows version 5.6. Ciência Agrotecnologia, 38(2), 109-112. https://doi.org/10.1590/S1413-70542014000200001

Gomes, F. P. (2009). Curso de estatistica experimental (15th ed., p. 451). Piracicaba: FEALQ. 
Guerra, A. G., Medeiros, A. A., Moreira, M. A. B., Dantas, J. A., \& Medeiros, A. C. (2009). Tecnologia para o cultivo da bananeira (1st ed., p. 42). Natal: EMPARN.

IBGE (Instituto Brasileiro de Geografia e Estatística). (2014). Levantamento sistemático da produção agrícola. Rio de Janeiro, 29(1), 1-83.

Lédo, A. S., Silva Junior, J. F., Lédo, C. A. S., \& Silva. S. O. (2008). Avaliação de genótipos de bananeira na região. Revista Brasileira de Fruticultura, 30(3), 691-695. https://doi.org/10.1590/S0100-2945200800 0300022

Maia, P. M. E., Alves, F. I. S., Lima, A. S., Pereira, R. F., Cavalcante, S. N., \& Santos, J. G. R. (2011). Crescimento vegetativo da bananeira Nanica (Musa sp.) em função do uso de diferentes tipos e dosagens de biofertilizante. VII Congresso Brasileiro de Agroecologia, Fortaleza. Anais... CD-ROM.

Manly, B. F. J. (2008). Multivariate statistical methods: A primer. In S. I. C. Carmona (Ed.), Métodos Estatísticos Multivariados: Uma introdução (3rd ed., p. 229). Porto Alegre: Bookman.

Melo, R. R. V., Araújo, J. J., Macchi, P. M., \& Santos, S. L. (2017). Tratamento fitossanitário do rizoma da bananeira variedade Pacovan para produção em sistema agroecológico no vale do Açu-RN. Retrieved from http://congressos.ifal.edu.br/index.php/connepi/CONNEPI2010/paper/viewFile/1782/1057

Mendonça, V., Gontijo, T. C. A., Arruda, N. A. A., Dantas, D. J., \& Martins, P. C. C. (2003). Propagação da Bananeira e Cuidados na Instalação do Pomar. Revista Eletrônica de Agronomia, 3(3).

Moita Neto, J. M. (2017). Estatística multivariada: Uma visão didática-metodológica (p. 13). Retrieved from http://www.pucrs.br/famat/viali/especializa/realizadas/ceea/multivariada/textos/Moita_Neto.pdf

Paula, J. A. A. (2017). Levantamento sistemático da produção agrícola: Planilha eletrônica EXCEL ${ }^{\circledR}$ para adaptação dos dados da análise conjunto de produção entre os Estados do Ceará e do Rio Grande do Norte fornecido em IBGE 2014 (p. 2). Mossoró, Brazil.

Rangel, A., Penteado, L. A. C., \& Tonet, R. M. (2017). Banana (Musa, sp.). Manual de Culturas-Cati. 2012 (p. 8). Retrieved from http://www.agrobyte.com.br/banana.htm 


\section{Appendix A}

Table A1. Physical-chemical analysis of the soil for purposes of fertility evaluation of the experimental area located in the municipality of Mossoró/RN, in Brazil, 2016

\begin{tabular}{|c|c|c|c|}
\hline \multicolumn{2}{|c|}{$\begin{array}{ll}\text { Item scanned } & \text { Sample Type } \\
\end{array}$} & \multirow{2}{*}{$\begin{array}{l}\text { Soil sample at depth } \mathbf{0 - 2 0} \mathbf{c m} \\
0.07\end{array}$} & \multirow{2}{*}{$\begin{array}{l}\text { Soil sample at depth } \mathbf{2 0 - 4 0} \mathrm{cm} \\
0.07\end{array}$} \\
\hline \multirow{5}{*}{ 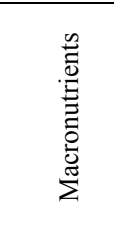 } & $\mathrm{N}(\mathrm{g} / \mathrm{Kg})$ & & \\
\hline & $\mathrm{P}\left(\mathrm{mg} / \mathrm{dm}^{3}\right)$ & 2.0 & 1.2 \\
\hline & $\mathrm{K}^{+}\left(\mathrm{Cmol}_{\mathrm{C}} / \mathrm{dm}^{3}\right)$ & 24.5 & 15.6 \\
\hline & $\mathrm{Ca}^{2+}\left(\mathrm{Cmol}_{\mathrm{C}} / \mathrm{dm}^{3}\right)$ & 1.27 & 1.13 \\
\hline & $\mathrm{Mg}^{2+}\left(\mathrm{Cmol}_{\mathrm{C}} / \mathrm{dm}^{3}\right)$ & 0.32 & 0.25 \\
\hline \multirow{4}{*}{ 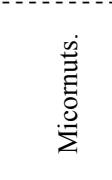 } & $\mathrm{Cu}\left(\mathrm{mg} / \mathrm{dm}^{3}\right)$ & 0.68 & 0.34 \\
\hline & $\mathrm{Fe}\left(\mathrm{mg} / \mathrm{dm}^{3}\right)$ & 12.4 & 13.6 \\
\hline & $\operatorname{Mn}\left(\mathrm{mg} / \mathrm{dm}^{3}\right)$ & 1.7 & 3.4 \\
\hline & $\mathrm{Zn}\left(\mathrm{mg} / \mathrm{dm}^{3}\right)$ & 0.5 & 1 \\
\hline \multicolumn{2}{|c|}{$\mathrm{CE}(\mathrm{dS} / \mathrm{m})$} & - & - \\
\hline \multicolumn{2}{|l|}{ pH (água) } & 7.67 & 7.64 \\
\hline \multicolumn{2}{|c|}{ Mat. Org. (g/Kg) } & 4.17 & 7.91 \\
\hline \multicolumn{2}{|c|}{$\mathrm{Na}^{+}\left(\mathrm{Cmol}_{\mathrm{C}} / \mathrm{dm}^{3}\right)$} & 21.3 & 14.2 \\
\hline \multicolumn{2}{|c|}{$\mathrm{Al}^{3+}\left(\mathrm{Cmol}_{\mathrm{C}} / \mathrm{dm}^{3}\right)$} & 0 & 0 \\
\hline \multicolumn{2}{|c|}{$\mathrm{H}+\mathrm{Al}\left(\mathrm{Cmol}_{\mathrm{C}} / \mathrm{dm}^{3}\right)$} & 0 & 0 \\
\hline \multicolumn{2}{|c|}{$\mathrm{SB}\left(\mathrm{Cmol}_{\mathrm{C}} / \mathrm{dm}^{3}\right)$} & 1.75 & 1,48 \\
\hline \multicolumn{2}{|c|}{$\mathrm{t}\left(\mathrm{Cmol}_{\mathrm{C}} / \mathrm{dm}^{3}\right)$} & 1.75 & 1.48 \\
\hline \multicolumn{2}{|c|}{$\mathrm{CTC}\left(\mathrm{Cmol}_{\mathrm{C}} / \mathrm{dm}^{3}\right)$} & 1.75 & 1.48 \\
\hline \multicolumn{2}{|l|}{ V $(\%)$} & 100 & 100 \\
\hline \multicolumn{2}{|l|}{$\mathrm{m}(\%)$} & 0 & 0 \\
\hline \multicolumn{2}{|l|}{ PST (\%) } & 5 & 4 \\
\hline \multirow{3}{*}{ 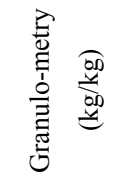 } & Areia & 0.82 & 0.85 \\
\hline & Silte & 0.02 & 0.02 \\
\hline & Argila & 0.16 & 0.13 \\
\hline \multicolumn{2}{|c|}{ Textural Class * } & 12 & 12 \\
\hline \multicolumn{2}{|c|}{ Silte/clay ratio } & 0.14 & 0.15 \\
\hline
\end{tabular}

Note. *: The Textural Class revealed to both depths sand texture. 
Table A2. Chemical analysis of the water used in the banana experimental area, located in the municipality of Mossoró/RN, in Brazil, 2016

\begin{tabular}{lll}
\hline \multicolumn{1}{c}{ Item scanned } & Sample Type & \\
\hline $\mathrm{pH}$ & (water) & 7.18 \\
$\mathrm{CE}$ & $\mathrm{dS} / \mathrm{m}$ & 0.67 \\
$\mathrm{~K}^{+}$ & $\mathrm{mmol}_{\mathrm{C}} / \mathrm{L}$ & 0.43 \\
$\mathrm{Na}^{+}$ & $\mathrm{mmol}_{\mathrm{C}} / \mathrm{L}$ & 2.05 \\
$\mathrm{Ca}^{2+}$ & $\mathrm{mmol}_{\mathrm{C}} / \mathrm{L}$ & 2.16 \\
$\mathrm{Mg}^{2+}$ & $\mathrm{mmol}_{\mathrm{C}} / \mathrm{L}$ & 1.33 \\
$\mathrm{Cl}^{-}$ & $\mathrm{mmol}_{\mathrm{C}} / \mathrm{L}$ & 2.60 \\
$\mathrm{CO}_{3}{ }^{2-}$ & $\mathrm{mmol}_{\mathrm{C}} / \mathrm{L}$ & 0.00 \\
$\mathrm{HCO}_{3}{ }^{-}$ & $\mathrm{mmol}_{\mathrm{C}} / \mathrm{L}$ & 4.10 \\
$\mathrm{~N}$ & $\mathrm{mg} / \mathrm{L}$ & - \\
$\mathrm{P}$ & $\mathrm{mg} / \mathrm{L}$ & - \\
$\mathrm{RAS}^{2}$ & & 1.60 \\
Toughness $_{\mathrm{Cátions}}$ & $\mathrm{mg} / \mathrm{L}$ & 174.50 \\
$\hat{A}_{\text {nions }}$ & $\mathrm{mmol} / \mathrm{L}$ & 6.00 \\
\hline
\end{tabular}

\section{Copyrights}

Copyright for this article is retained by the author(s), with first publication rights granted to the journal.

This is an open-access article distributed under the terms and conditions of the Creative Commons Attribution license (http://creativecommons.org/licenses/by/4.0/). 